\title{
Accounting Information System for Non-Subsidized Fertilizer Sales at PT Petrokimia Gresik
}

\author{
ANAK AGUNG GDE SATIA UTAMA ${ }^{1}$, HADIYAN AZMI HUSSEIN ${ }^{2}$ \\ ${ }^{1}$ Accounting Department, UNIVERSITAS AIRLANGGA, INDONESIA. E-mail: gde.agung@feb.unair.ac.id \\ ${ }^{2}$ Accounting Department, UNIVERSITAS AIRLANGGA, INDONESIA. E-mail: hadiyan.azmi.hussein- \\ 2016@feb.unair.ac.id
}

\begin{abstract}
Nowadays, knowledge is essential in all aspects of human life. Decisions need to consider information. The higher the quality of knowledge, the more effective the decision-making. The objectives this study are to analyze the accounting information system of on-subsidized fertilizer sales Petrokimia Gresik. This study uses a qualitative method, and the scope of analysis focuses on the non-subsidized fertilizer sales accounting information system. The data acquired from observation and documentation. The data collection from preliminary surveys, literature studies, and field surveys, then analyzed using flowcharts. The results of this research propose a new flowchart that uses an input-process-output method for the non-subsidized fertilizer sales accounting information system. This research shows that in other organizations with unique characteristics, the suggested systematic approach can be applied.
\end{abstract}

Keywords: Analysis Accounting Information System; Case Study; Petrokimia Gresik; Sales of Fertilizer.

JEL Classification: M10, M150, M410

Received: June 02, 2021

Accepted: October 01, 2021 


\title{
Sistema de Información Contable para la Venta de Fertilizantes no Subvencionados (Estudio de Caso en PT Petrokimia Gresik)
}

\author{
ANAK AGUNG GDE SATIA UTAMA ${ }^{1}$, HADIYAN AZMI HUSSEIN ${ }^{2}$ \\ ${ }^{1}$ Accounting Department, UNIVERSITAS AIRLANGGA, INDONESIA. E-mail: gde.agung@feb.unair.ac.id \\ ${ }^{2}$ Accounting Department, UNIVERSITAS AIRLANGGA, INDONESIA. E-mail: hadiyan.azmi.hussein- \\ 2016@feb.unair.ac.id
}

\begin{abstract}
RESUMEN
Hoy en día, el conocimiento es fundamental en todos los aspectos de la vida humana. Las decisiones deben considerar la información. Cuanto mayor sea la calidad del conocimiento, más eficaz será la toma de decisiones. Los objetivos de este estudio son analizar el sistema de información contable de la venta de fertilizantes subvencionados Petrokimia Gresik. Este estudio utiliza un método cualitativo y el alcance del análisis se centra en el sistema de información contable de ventas de fertilizantes no subsidiados. Los datos constan de datos primarios y secundarios. La recopilación de datos de encuestas preliminares, estudios de literatura y estudios de campo, luego se analiza mediante diagramas de flujo. Los resultados de esta investigación proponen un nuevo diagrama de flujo que utiliza un método de entrada-proceso-salida para el sistema de información contable de ventas de fertilizantes no subsidiados. El sistema ERP integrado (Enterprise Resource Planning System) tiene como objetivo integrar toda la información corporativa en una base de datos central, para permitir que los datos se recuperen de múltiples roles organizacionales diferentes $y$, en principio, hacer visible cualquier objeto ejecutivo. Esta investigación muestra que en otras organizaciones con características únicas, se puede aplicar el enfoque sistemático sugerido.
\end{abstract}

Palabras clave: Sistema de Información Contable Análisis; Caso de Estudio; Petrokimia Gresik; Ventas de Fertilizantes; Ventas.

Clasificación JEL: M10, M150, M410

Recibido: 02 de Junio de 2021

Aceptado: 01 de Octubre de 2021 


\section{Introduction}

The accounting profession must deal with many dynamic issues that have never existed in the current computerized, interconnected global business environment (Shanikat 2008; Trigo, Belfo, \& Estébanez, 2014). A change of policy on business practices needs the scope of the business world's growth today (Lalić, Lalić, Drakul, \& Lalić, 2014). An important message of this review is that researchers in Accounting Information System (AIS) and other accounting fields, such as finance, auditing, taxation, and management, should work together to carry out projects because all parties can learn from each other.(Liebenau \& Lee, 1997; Lim, 2013; Shanikat, 2008; Trigo, Belfo, \& Estébanez, 2016)

Accounting information systems play an important role in providing information to managers (Basri, 2014; Dechow and Mouritsen, 2005; Ghasemi, Shafeiepour, Aslani, and Barvayeh, 2011; Liebenau and Lee, 1997; Lim, 2013; Tudent, 2012). Companies need to make profound technological advances to gain an advantage over the competition (Al-Hawari 2017; Soudani 2012). The sales department is formulating strategic plans to meet consumer needs and trade through the profits generated to achieve business continuity and outstanding business performance (Amiri \& Salari 2013; Boonmak, 2008; Lalić et al., 2014; Shanikat, 2008; Sori, 2009). Sales management is suitable for computerized accounting information systems (Iskandar, 2015).

PT Petrokimia Gresik is a company that produces the widest range of fertilizers in Indonesia. Its products include Urea, ZA, SP-36, ZK, NPK, Phonska, NPK Kebomas and Petroganik. It also produces non-fertilizer products such as sulfuric acid, phosphoric acid, ammonia, dry ice, aluminum fluoride, cement retarders, etc. When selling PT subsidized fertilizers, Petrokimia Gresik must comply with the Ministry of Internal Affairs and Administration No. 15 / M-DAG / PER / 6/2013 for purchase and distribution of subsidized fertilizers for the agricultural sector. This underlines that governments, producers, distributors, and retailers are involved in purchasing and distributing subsidized fertilizers. Therefore, they play an important role in subsidizing the purchase and disposal of fertilizers (Xu, 2009).

Fertilizers play an important role in increasing agricultural productivity, farmer's income and strengthening national food security (Rachman \& Sudaryanto, 2010; Shanikat, 2008). The company's work plan, sales budget, and sales performance for 2013 (Indonesian Rupiah). Urea showed a positive trend, with a completion rate of $263.8 \%$ and a sale of IDR $444,670,211,446$. One of the factors of its success was the construction of a new urea plant in plant 1 . On the other hand, NPK Fertilizer reached IDR $1,209,225,016,690$ in the sales plan of $1,605,833,425,000$, reaching $75,3 \%$ of the yield. It makes him the main producer of PT Petrokimia Gresik.

Similarly, ZA fertilizer also showed a good sales trend of $89.6 \%$, worth Indonesian rupiah. $76,056,200,027$ in the sales plan of $84,823,710,000$ rupiah. The company set the sales target of $\mathrm{KCL}$ Fertilizer at IDR $490,110,000,000$, but the realization shows that the result of IDR is unfortunate. $73,502,956,230$. The sales of SP36 fertilizer accounted for $28.7 \%$ of the Indonesian rupiah. $108,108,060,000$. ZK's fertilizer sales target is Indonesian Rupiah. 50,209,944,000, its realization showed a positive result at IDR 56,501,499,228 (112.53\%).

An Accounting Information System (AIS) combined with information technology tools is typically a computer-based tool for monitoring accounting operations. AIS is responsible for the compilation, storage, and analysis of financial and accounting data, including non-financial transactions that directly affect the processing of financial transactions (Al-Hawari, 2017; Amiri \& Salari 2013; Boonmak, 2008; Sori, 2009; Soudani, 2012), used for internal management decision-making.

Accounting is the mechanism used by a corporation to formulate its financial results by tracking and classifying all transactions (Soudani, 2012). Accounting method requires data collection, analysis, and presentation. Affordable software packages that automatically carry out registration, transition, estimation, clustering review, control plans, deviations from plans and preparation of financial statements are protected by the necessary details for all these activities. The implementation of this method brings substantial benefits of reducing workload and errors, improving data quality, transparency, and dynamism (Dilla, Janvrin, \& Raschke, 2010; Trigo et al., 2014; Xu, 2009. The use of 
information technology to perform accounting functions has created an impetus for companies to develop paperless offices (Ghasemi et al., 2011; Liebenau \& Lee, 1997; Lim, 2013).

The effectiveness of an accounting information system depends on technical challenges. Other factors, however, such as people and organizational dimensions, should be taken into account (Iskandar, 2015; Lim, 2013; Shanikat, 2008; Trigo et al., 2014). The growth of information technology has reached a stage where there is almost no field of existence in which its components are not included. A particular contribution is reflected by performance, cost-effectiveness, and all types and forms of business supported with information technology. Each business role is strengthened by implementing appropriate equipment and software applications in all kinds of business entities. In terms of the degree of manual service, one of the most detailed quantitative industries is undoubtedly the accounting industry (Lalić et al., 2014).

Sales accounting information system needs accurate input data and a proper data processing system (Klaus, Rosemann, \& Gable, 2000; Rachman \& Sudaryanto 2010; Trigo et al., 2014; Ullah, Baharun, Nor, \& Yasir, 2018) to generate accurate sales information for management decision-making. Data processing refers to the transformation of raw data into significant output (Daoyuan, 2011; Sori, 2009).

Data collection comprises distribution from its origin to the machine. Using a pen and paper, data may be performed manually, mechanically using basic instruments, such as typing, or electronically using modern data processing equipment, such as computers. As for data input, the data obtained were translated by an input system into a machine-readable form and sent to the device. Data processing is the conversion within the CPU of the input data into a more meaningful form (information). Output is the development of the necessary information that could be given in the future (Lalić et al., 2014).

In this research, sales are one of the essential activities for the business's survival significantly after the success of this operation (Alianto, Wijaya, \& Arlan, 2012). The role of sales accounting information system is necessary for achieving company's goals since it is a set of resources coordinated to collect, identify, process and interpret sales transaction data into valuable decision-making information from the company's internal and external (Al-Hawari, 2017; Ghasemi et al., 2011)

If there is no specific input data, the generated sales information will not conform to the actual situation (Dao Yuan, 2011). This is very important because significant failures may occur after management considers the case to be inappropriate. Processing information depends on the company's methods and procedures (Klaus et al., 2000; Liebenau \& Lee, 1997).

In Daoyuan (2011), Romney concluded that data refers to any collected facts stored and processed by an information system. Information is organized and prepared data to provide meaning. In a business system, procurement, development, and sales frequently occur in business processes. In these points, the accounting information system effectively promotes company's activities by preparing up-to-date accounts, providing as much information as possible, allowing experts to analyze the data, contributing through system network carefully, and tracking liquidity (Dechow \& Mouritsen, 2005; Liebenau \& Lee, 1997; Trigo et al., 2014). For this purpose, linking various modules for automated, efficient collaboration has become extremely important since it promotes evaluation, preparation, and decision-making, as the accounting information system is directly connected to the relevant areas (Abugabah \& Sanzogni, 2009; Dechow \& Mouritsen, 2005; Ullah et al., 2018). ERP software should ensure a connected application for management and reporting, with particular significance for the components that support the accounting information system (Abugabah \& Sanzogni, 2009; Klaus et al., 2000; Tudent, 2012; Ullah et al., 2018).

This research paper is organized as follows. A general overview of information system and technology follow the section of qualitative analysis techniques, qualitative research strategies and the study of qualitative data. Results and discussion, and conclusions were presented after. 


\section{Methodology}

This section in Accounting Information Systems is dedicated to qualitative analysis (AIS). To understand and describe social phenomena, qualitative research involves qualitative data such as interviews, records, and participant observation data. With a wide variety of approaches, methods, and techniques, qualitative researchers can be found in many disciplines and fields. There has been a general shift in AIS research from technical to managerial and organizational problems in Accounting Information Systems, which has increased interest in the use of qualitative research methods (Basri, 2014; Liebenau \& Lee, 1997; Myers, 1997; Parker, 2012).

The research method is a scientific way to discover, prove and build information that can be used to understand, predict, and solve problems to bring valid data to the destination. Based on the meanings disclosed above, it can be assumed that the methods used in this analysis are descriptive research methods to draw conclusions based on the study's problems. A significant aspect of any research project is the choice of a specific methodology, which will affect the type of analysis carried out and the adopted research methods and the results (Basri, 2014; Maxwell \& Kaplan, 2005; Myers, 1997; Parker, 2012).

The analysis used for the methodology is a qualitative approach. Qualitative research, based on interpretivism and constructivism, has been generally defined as any kind of research producing results that have not been obtained by statistical procedures or other means of quantification. The qualitative researcher seeks to gain an in-depth understanding of phenomena, acknowledging that it is impossible to capture an existential objective fact. The qualitative tradition tends to lead to the awareness and critique of management and accounting systems and the ability to answer practitioners' and policymakers' concerns. This study is needed to assess business process flow, information availability and requirements, technology application, and to observe business process performance and a questionnaire, which is a data collection technique, by providing a set of written questions (Basri, 2014; Liebenau \& Lee, 1997; Maxwell \& Kaplan, 2005; Myers, 1997; Parker, 2012). This method processes data in the form of written sentences, oral statements, behaviors, phenomena, events, and a new kind of knowledge while at the same time explaining the research objects in detail and in-depth to obtain solutions to problems (Dilla et al., 2010). The data obtained from observations, interviews, and document reviews are a form of descriptive qualitative methods. This study uses exploration points to describe the events in the event. It represents a series of occurrences without explaining the frequency of occurrence.

The analysis outcome of the PT Petrokimia Gresik sales method can be defined by the basic inputprocess-output as follows:

a. The organization of an organization

The organizational system does not separate subsidized and non-subsidized fertilizers. As activities and human resources will be more concentrated, activities will proceed more smoothly. Since the project is oriented towards the future, time feasibility can be used in the long run. Finally, since it directly impacts increasing sales in each department, it should focus on achieving the best results that are economically viable.

b. Input

There is no corresponding serial number between the application form, the admission notice, and the ERPB fund. This can lead to evaluation errors, storage confusion, and matching discrepancies. In addition, there are still manual inputs that hinder the process. It is necessary to provide the forms available on the website to place orders by replacing written memos in the database, allowing them to supervise each other. Due to the rapid development of technology recently, it can meet technical feasibility. Due to the possibility of action, the proprietary plan is considered feasible because it has undoubtedly achieved its intended purpose. The third level of qualification is the reality of time. Compared to the current operating system, the author's proposal has long-term expectations and future economic feasibility. 


\section{c. Process}

The integration of accounting information systems provides the infrastructure to define and validate hypotheses and transform tutors from abstract data descriptions into more comprehensive records of organizational activities. Organizations with information integration systems have a good understanding of how knowledge management can improve business outcomes (Alianto et al., 2012; Lalić et al., 2014). In addition, companies using information systems integration are believed to have a great deal of knowledge on auditing accounting systems to help companies improve efficiency.

System integration integrates component subsystems into an operating system. To maintain efficient and reliable data analysis, it ensures that all components work together. Typical information exchange includes customer information, orders, production line information, customer requests, etc. System integration is critical because it can establish connections between these different systems that do not normally interact.

\section{d Output}

The output of existing computerized systems will not produce maximum results because several activities are done manually. Therefore, the lack of responsiveness and accuracy of data processing affects the accuracy of sales reports. The proposal includes everything and is very feasible and can provide private parties with reports for evaluation. However, even though PT Petrokimia Gresik already has advanced software technology, creating the monthly turnover realization report is still manually generated.

\section{Results and Discussion}

A multi-component fertilizer was introduced into production with a total production capacity of 4 500.00 tons / year. The company is a comprehensive fertilizer producer in Indonesia with 23 factories under its control.

Computerized accounting standards play an important role in processing accounting data and applying accounting knowledge in structured accounting standards and efficiency, and supporting the research and development of accounting theory and technology. The automated AIS could accelerate the process of knowledge and resolve conventional human weaknesses. It will enhance organizational capabilities in precision, ease of use, reliability, timeliness, content, format, and satisfaction. The matrix of these factors consists of different item resources to improve management efficiency and data quality (Belfo \& Trigo, 2013; Maxwell \& Kaplan, 2005; Soudani, 2012; Trigo et al., 2014, Mendo, 2019).

Information technology and AIS are crucial factors for time-saving and removing location constraints, enhancing rapid access to information, allowing AIS and software setup to change working methods, and provide an electronic foundation. Through designing extensive training programs to obtain adequate knowledge of the accounting information system application and the value of data quality management, improved performance in corporate accounting software can be achieved by delivering better, more accurate, applicable, and comparable financial information in the current economic climate (Iskandar, 2015; Liebenau \& Lee, 1997; Maxwell \& Kaplan, 2005; Shanikat, 2008; Trigo et al., 2016).

The company's extensive resource planning system (ERP system) is designed to integrate all company information into a central database, allowing data to be collected from multiple organizational roles. In principle, any organizational object can be accessed. While only in recent years has the comprehensive and tight integration of enterprise resource planning systems (ERP) become possible, ERP has a pedigree of massive, bundled application software commonly used since the 1970s. (Klaus et al., 2000; Tudent, 2012; Ullah et al., 2018). In the final stage, the accounting department will receive an invoice from the sales department to make sure that the VAT has been paid. Later, the sales department will prepare the ledger. This ERP provides an advantage for suppliers to track consumer demand and supply patterns faster (Dechow \& Mouritsen, 2005; Sadrzadehrafiei, Chofreh, Hosseini, and Sulaiman, 2013; T \& M, 2019). 
A computer system is essential for getting accurate results. As the company's PP department itself also uses software, the proposal can be implemented from a technical point of view. In terms of operational feasibility, the project is targeted at private groups. If comprehensive information is available, both parties will be satisfied. The third qualification is the reality of time. The advice given by the developer can be applied at any point in the future as this has the advantage of increasing sales through evaluation. From the point of view of economic feasibility, the proposal will cause all sides of society to constantly consider what needs to be improved or added, which will undoubtedly affect the company's commercial finances.

The proposed program will bring some benefits. Since the data is stored in the database, the storage of sales data will be better organized. The traditional method of using non-integrated information systems may inhibit the low decision-making information for operational purposes and the strategic benefits of the company's market growth. To obtain fast, reliable, and accurate decision-making information, organizations need to introduce automated information systems. Improve the smoothness of data in the business value chain at the model stage. Ultimately, the company will have a competitive advantage over the company that still applies the system manually. Analyzing the sales process to obtain an image of the sales process and developing a sales information system based on users, managers, customers, and stakeholders can improve company performance.

According to the research results of the sales information system review, it is necessary to improve the internal operation efficiency of the sales business process by identifying the order status, real-time inventory status information, and promoting accurate and up-to-date display-sales report.

A strategic plan is needed to optimize integrated information systems by adopting an ERP system with web-based applications. This will make work more effective because managers and CEOs can easily track operations and make decisions without relying on location and time (Boonmak, 2008; Pati, 2019).

\section{Conclusion}

Advances in information technology are encouraging companies to computerize their information systems. As a result, the accounting information system has also been computerized. Accountants must learn to use computer systems as accounting information systems. The use of computerized accounting information systems gives enterprises the possibility of more efficient and effective accounting, as the computerized AIS system significantly saved time and costs. The use of IT for accounting has brought benefits to companies moving towards a paperless office. If an automated system is used, the company will be more efficient.

The PP department of the enterprise uses a computerized and ERP-based sales information system, although it is partially used. It has a computerized DO for customer orders, invoicing, and inspection of each truck. In a manual system process, operations are performed by each authorized person. Each team is responsible for each customer. PT Petrokimia Gresik, especially the PP department of the enterprise, has to continuously improve the sales system and internal control to create an outstanding performance.

Therefore, future research ought to look for other sources of information and be more interactive when interviewing respondents to obtain more accurate information. The existing regulations should be reconfirmed to assure their changes so that all information can be outdated for the next few years.

\section{References}

1. Abugabah, A., \& Sanzogni, L. (2009). Enterprise Resource Planning Systems (ERP) and user performance: A literature review. ACIS 2009 Proceedings - 20th Australasian Conference on Information Systems, 820-829.

2. Al-Hawari, F. (2017). Analysis and Design of an Accounting Information System. International Research Journal of Electronics and Computer Engineering, 3(2), 16. 
https://doi.org/10.24178/irjece.2017.3.2.16

3. Alianto, H., Wijaya, S. F., \& Arlan, F. (2012). AN ANALYSIS OF SALES INFORMATION SYSTEM AND COMPETITIVE ADVANTAGE (Study Case of UD. Citra Helmet). CommIT (Communication and Information Technology) Journal, 6(2), 69. https://doi.org/10.21512/commit.v6i2.572

4. Amiri, A., \& Salari, H. (2013). Effect of Accounting Information System (AIS) on Software qualitative. International Journal of Business and Management Invention ISSN (Online, 2(4), 2319-8028.

5. Basri, H. (2014). Using Qualitative Research in Accounting and Management Studies: Not a New Agenda. Journal of US-China Public Administration, 11(10), 831-838. https://doi.org/10.17265/1548-6591/2014.10.003

6. Boonmak, S. (2008). Strategically Involved, Accounting Information Systems Change The Way Businesses Compete. 3-18.

http://citeseerx.ist.psu.edu/viewdoc/download;jsessionid=8D0F660995B53F5943CEA3A9BDCC9D $6 \mathrm{C}$ ?doi=10.1.1.616.8023\& rep=rep1\&type $=$ pdf

7. Daoyuan, S. (2011). Design of accounting information system based on E-commerce. 2011 International Conference on E-Business and E-Government, ICEE2011 - Proceedings, 105, 68646867. https://doi.org/10.1109/ICEBEG.2011.5886819

8. Dechow, N., \& Mouritsen, J. (2005). Enterprise resource planning systems, management control and the quest for integration. Accounting, Organizations and Society, 30(7-8), 691-733. https://doi.org/10.1016/j.aos.2004.11.004

9. Ghasemi, M., Shafeiepour, V., Aslani, M., \& Barvayeh, E. (2011). The impact of information technology (it) on modern accounting systems. Procedia - Social and Behavioral Sciences, 28, 112 116. https://doi.org/10.1016/j.sbspro.2011.11.023

10.Iskandar, D. (2015). Analysis Of Factors Affecting The Success Of The Application Of Accounting Information System. International Journal of Scientific \& Technology Research, 4(2), 155-162.

11.Klaus, H., Rosemann, M., \& Gable, G. G. (2000). What is ERP ? Information Systems Frontiers, 2(2), 141-162.

12.Lalić, N., Lalić, S. S., Drakul, B., \& Lalić, S. S. (2014). Accounting in the integrated management information system. 2014 International Conference on Economics, Management and Development, 119-123. http://www.inase.org/library/2014/interlaken/ECON.pdf\#page=119

13.Lee, A. S. (1997). Information Systems and Qualitative Research. i, 1-8.

14.Lim, F. P. C. (2013). Impact of Information Technology on Accounting Systems. Asia-Pacific Journal of Multimedia Services Convergent with Art, Humanities, and Sociology, 3(2), 93-106. https://doi.org/10.14257/ajmscahs.2013.12.02

15.Maxwell, J. A., \& Kaplan, B. (2005). Qualitative Research Methods for Evaluating Computer Information Systems. Healthcare Information System, 30-56.

16. Mendo, A. Y,. (2019). Analysis of Knowledge Management, Work Innovation on Achievements and Progress of Gorontalo Province's Government Organizations. Asia Pacific Journal of Management and Education.

17.Myers, M. D. (1997). Qualitative research in information systems. MIS Quarterly: Management Information Systems, 21(2), 241-242. https://doi.org/10.2307/249422

18.Parker, L. D. (2012). Qualitative management accounting research: Assessing deliverables and relevance. Critical Perspectives on Accounting, 23(1), 54-70.

https://doi.org/10.1016/j.cpa.2011.06.002

19.Pati, A. (2019). The Influence of Leadership and Organizational Culture on Employee Work Satisfaction in Bolmut Regency. Asia Pacific Journal of Management and Education.

20.Rachman, B., \& Sudaryanto, T. (2010). IMPACTS AND FUTURE PERSPECTIVES OF FERTILIZER POLICY IN INDONESIA Dampak dan Perspektif Kebijakan Pupuk di Indonesia ( $90 \%$ ) buy subsidized fertilizer at prices higher than the highest retail prices . In Programs and to overcome this problem, the governm. Analisis Kebijakan Pertanian, 8(3), 193-205. pse.litbang.pertanian.go.id/eng/pdffiles/ART8-3a.pdf

21.Shanikat, M. (2008). Organisational change and accounting information systems : a case study of the privatisation of Jordan Telecom. 272. 
22.Sori, Z. M. (2009). Accounting Information Systems (AIS) and Knowledge Management: A Case Study. American Journal of Scientific Research ISSN, 1450(4), 36-44.

http://www.eurojournals.com/ajsr.htm

23.Soudani, S. N. (2012). The Usefulness of an Accounting Information System for Effective Organizational Performance. International Journal of Economics and Finance, 4(5), 136-145. https://doi.org/10.5539/ijef.v4n5p136

24.Trigo, A., Belfo, F., \& Estébanez, R. P. (2014). Accounting Information Systems: The Challenge of the Real-time Reporting. Procedia Technology, 16, 118-127.

https://doi.org/10.1016/j.protcy.2014.10.075

25.Trigo, A., Belfo, F., \& Estébanez, R. P. (2016). Accounting Information Systems: Evolving towards a Business Process Oriented Accounting. Procedia Computer Science, 100, 987-994. https://doi.org/10.1016/j.procs.2016.09.264

26.Tudent, P. H. D. S. (2012). The Current Role of Accounting Information Systems. Theory Methodology Practice (TMP), 8(01), 91-95.

27.Ullah, A., Baharun, R. Bin, Nor, K. M., \& Yasir, M. (2018). Overview of Enterprise Resource Planning (ERP) System in Higher Education Institutions (HEIs). Advanced Science Letters, 24(6), 4399-4406. https://doi.org/10.1166/asl.2018.11614 